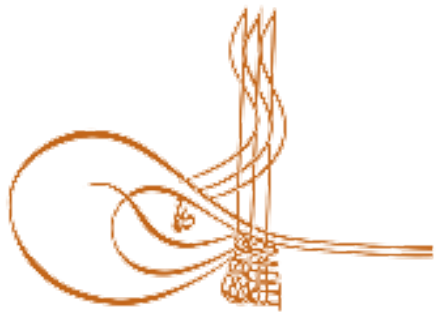

www.turkishstudies.net/education
Turkish Studies - Educational Sciences

eISSN: $2667-5609$

Research Article / Araștırma Makalesi

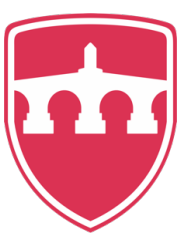

INTERNATIONAL

BALKAN

UNIVERSITY

Sponsored by IBU

\title{
Üniversite Öğrencilerinin Bağlanma Stilleri ile Prososyal Davranış Arasındaki İlişkilerin İncelenmesi*
}

\author{
Examination of the Relationship Between Attachment Styles of the University Students and \\ Prosocial Behavior
}

\author{
Fatma Nur Tekin $^{* *}$ - Mehmet Kandemir ${ }^{* * *}$
}

\begin{abstract}
The aim of this study is to examine the relationships between attachment style and prosocial behavior of the university students. The research which is used relational survey method was carried out on 551 students who are among 1st and 4th grades and are attending to Kırıkkale University in the 2018-2019 academic year. Prosocial Scale which is developed by Carlo and Randal (2002) and is adopted by Yıldız, Boz and Yildirım (2012) to university students and Interpersonal Attachment Styles Scale which is developed by Kandemir and İlhan (2017) are used in the research as data collection tools. Path analyse method was used by utilizing AMOS package programs in order to analyse hypothesis test model. As a result of the research, it is revealed that secure attachment style of the university students has a precursor power which is significant and positively on Compliant Prosocial Behavior and is significant and positively on the anonymous/altruist behavior. According to reserach findings, anxious attachment sytle has positive and significant effect on predicting public prosocial behavior and pragmatic prosocial behavior. There withal the avoidant attachment style predicts public prosocial behavior positively and substantially and pragmatic prosocial behavior positively and substantially. The findings obtained after the analysis of research are discussed by comparing with the literature study results. In the last part of the research, suggestions are made within the results of the study.
\end{abstract}

Structured Abstract: Introduction: Help, also referred to in the literature as positive social behavior or prosocial behavior, is a behavior that increases social solidarity, provides awareness of being a society and is expected to be one of the factors that form the basis of the individual's socialization process (Çek, 2013). According to Kim and Stevens (1987), positive social behaviors such as helping and sharing make it easier for

\footnotetext{
* Bu çalışma "Üniversite Öğrencilerinin Bağlanma Stilleri ile Prososyal Davranış Arasındaki İlişkilerin İncelenmesi” adlı yükssek lisans tezinden üretilmiştir. Bu çalışmanın verileri Nisan 2019 tarihinde toplanmıştır.

${ }_{* *}^{*}$ Uzman Psikolojik Danışman, Türkiye Cumhuriyeti, Milli Eğitim Bakanlığı.

Specialist Psychological Counselor, Republic of Turkey, Ministry of National Education

ORCID 0000-0003-3991-331X

fntekin@gmail.com

*** Doç. Dr., Kırıkkale Üniversitesi, Eğitim Fakültesi, Eğitim Bilimleri Bölümü

Associate Professor, Kırıkkale University, Faculty of Education, Educational Sciences Department

ORCID 0000-0002-5576-3537

mkandemir61@gmail.com

Cite as/ Atıf: Tekin, F. N. \& Kandemir, M. (2020). Üniversite öğrencilerinin bağlanma stilleri ile prososyal davranış arasındaki ilişkilerin incelenmesi, Turkish Studies - Education, 15(2), 1213-1231. https://dx.doi.org/10.29228/TurkishStudies.39977

Received/Geliş: 02 December/Aralık 2019

Accepted/Kabul: 25 April/Nisan 2020

Copyright $(\mathrm{INTAC}$ LTD, Turkey 
individuals to bond with society and maintain these bonds in a healthy way. Attachment, which is one of the basic concepts of socialization, is defined as the strong emotional attachment that people develop towards people who are important to them and influences prosocial behavior (Bowlby, 1982). Accordingly, this research is important for understanding the developmental process of attachment and the role of prosocial behavior in the process

\section{Literature Review}

Prosocial behavior is a concept based on the voluntary assistance an individual gives others. This concept was put forward in the 1960s as a counter definition to an individual's behavior to help others and as on opposition to anti-social behavior (Bilgin, 1988). Carlo, Hausmann, Christiansen, and Randall (2003), defines prosocial behavior as behaviors one performs fort he benefit of others without being under pressure, at their own will. However, since these definitions are very general, they bring with them some limitations. Such definitions do not take into account the intention of the person performing the prosocial behavior and the quality of the assistance provided (Dove, Carlo and Edwards, 2004). Bekkers and Graaf (2005) Express that prosocial behavior is often considered a form of 'altruistic behavior', depending on the individual's moral qualities and altruistic personality tendencies. Carlo et al (2003) collected the dimensions of prosocial behavior into six titles. These are public, anonymous, dire, emotional, compliant and altruistic.

Public prosocial behaviors have been defined as willing behaviors that are seen in the presence of others. Anonymous prosocial behaviors have been described as a tendency to help others without the knowledge of others. Dire prosocial behaviour means helping others in emergencies or crisis situations. Emotional prosocial behaviors are behaviors that come to life in situations where an emotional reminder is present. Compliant prosocial behavior is the individual helping others upon request. Altruism is to help others when there is little or no potential for a perceived direct and obvious reward to oneself (Carlo et al., 2003).

Bowlby gave priority to the child's emotional development in his attachment theory, which he based on psychoanilytic theory. The basic point of the theory is that the mother figure (the person who does the work of the mother) creates a safe environment for the child in the outside world (Tüzün ve Sayar, 2006). Ainsworth took Bowlby's theory to the experimental environment and divided it into three categories. Individuals with secure attachment have a more positive outlook on social life. These individuals are generally happy in their relationships and have a sense of acceptance by others (Hamarta, 2004). Individuals who are securely connected see others as individuals who are worthy of being loved, well-intentioned, and have positive thoughts. Individuals with anxious/unstable attachment styles are comfortable in forming relationships with others but often experience fear of being disliked, abandoned (Hamarta, 2004). They have an obsessive and jealous attitude, often experiencing emotional ups and downs in their relationships (Sumer and Güngör, 1999). Individuals who have a avoiding attachment style are defined as people who rely less on others than those who have two other styles, have negative expectations in their relationships, and avoid intimacy (Sumer and Güngör, 1999). They are skeptical, overly fragile or prone to disappointment in their relationships. They often think that they are not loved and that others are not worthy of being loved. This situation occurs because the necessary care and attention shown during childhood is insufficient and a negative reaction against the mother occurs as a result of meeting the necessary attention when the mother wants it rather than when the child wants it (Hamarta, 2004).

\section{Method}

The working group of this study consists of 551 students. However, due to the incomplete response of the data during the data cleaning, the data taken from two individuals was removed and the analysis was started with 549 data. The first of the scales to be applied to students is the prosocial behavior scale is a twentyfour item scale developed by Carlo and Randal (2002) to measure the tendency of prosocial behavior in a university student sample and adapted to Turkish by Dove, Carlo and Edwards (2004) for young people aged 11-21 years. The other scale is the twenty-one item scale of attachment styles in interpersonal relationships, developed by Kandemir and Ilhan (2017), taking into account Bowbly's attachment theory.

\section{Findings and Discussion}

According to the research findings, anxiety attachment style has a positive and meaningful effect in predicting public prosocial behavior and positive and meaningful effect in predicting utilitarian prosocial 
behavior. It has also been found that the avoidant attachment style predicts public prosocial behavior in a positive way, and utilitarian prosocial behavior in a meaningful and positive way.

As a result of the research, it was found that attachment styles significantly predict prosocial behavior. When we look at the predictability of attachment styles, it is seen that safe attachment predicts anonymous and compliant prosocial behavior in a positive way, which we can call a positive aspect of prosocial behavior. Although there are no studies directly supporting this situation, it has been observed that concepts related to prosocial behavior (such as empathy, altruism, social skill) have a positive relationship with secure attachment (Guerro and Jones, 2003; Sambo, 2010).; Hurter, 2014). Also known as insecure attachment styles, anxious and avoidant attachment styles positively predict utilitarian and public prosocial behavior, which can be seen as the negative aspect of prosocial behavior. According to this conclusion, it is observed that individuals who are insecure have shown public and utilitarian prosocial behavior. However, the expected situation is that individuals display anonymous and compliant prosocial behavior that constitutes the voluntary dimensions of prosocial behavior and represents internal help. In other words, Insecure connected individuals are expected to perform prosocial behavior internally and without any benefit, as in individuals with a secure attachment style, instead of exhibiting purposeful prosocial behavior that is at the forefront of their own benefits, such as receiving approval from society. The conceptual model that emerged as a result of the analysis of this research supporting this situation shows that avoiding and anxious attachment predicts public and utilitarian prosocial behavior, while secure attachment style predicts anonymous/altruistic and compliant prosocial behavior. According to Eisenberg, Fabes, and Spinrad (2006) the findings on the relationship between secure attachment of child and his/her prosocial tendencies indirectly support that strong and close family relationships positively affect prosocial development of the child as sucurely attached children have an attachment figure who cares about their well-being. For individuals who have achieved secure attachment, helping others does not help their personal protection goals. Because the individual already feels safe. On the contrary, as he experiences a sense of security, he releases the energy and attention he will expend on self-preservation and allows him to exhibit empathetic attitudes (Shaver, Mikulincer and Chun, 2008). This supports this research.

It can also be said that the figure in which attachment is achieved on prosocial behavior has an effect. The fact that the baby is bonding with the figure means that the figure is with the baby at times of need, and it is known that babies use modeling methods in learning. Accordingly, it may be important for the figure to be a model in the learning of prosocial behavior, which is a behavior.

\section{Conclusion and Recommendations}

Research has shown that attachment styles have an effect on prosocial behavior. According to this study, it was concluded that safe attachment style positively predicts the dimensions of prosocial behavior and submissive prosocial behavior; whereas anxious attachment style and avoidant attachment style positively predicts utilitarian prosocial behavior and public prosocial behavior. It can be said that individuals who have attained secure attachment perform prosocial behavior willingly, without hesitation or expectation of anything in return and without publicity whereas indivduals who have attained avoiding or unstable attachment tend to perform prosocial behavior publicly and with the hope of getting something in return. Accordingly, the result was that attachment styles are an important variable that predicts prosocial behavior.

Research has shown that individuals ' attachment styles influence positive social behavior. The basics of prosocial behavior in individuals are also shaped by the formation of attachment styles at a young age. In this case, the attachment style of the individual is important. Education can be given to the the mother figure, who will be connected with the subject, and the positive social behavior that society needs can be increased. In determining attachment styles, considering the impact of the caregiver, projects such as family education can be carried out to enable parents to perform their roles and functions in the family more effectively.

According to the research, individuals who perform avoidant and anxious attachment styles are less likely to participate, stand behind, and have a more background in social relationships than those who perform safe attachment within society. Individuals with insecure attachment styles (anxious and avoidant) can be given related trainings to raise awareness about attachment styles. Thus, self-believers can also be more comfortable performing prosocial behavior.

Keywords: Educational Sciences, Attachment Styles, Prosocial Behavior, Positive Social Behavior, Help 
Öz: Bu araştırmanın amacı, üniversite öğrencilerinin sahip oldukları bağlanma stili ile prososyal davranış arasındaki ilişkilerin incelenmesidir. İlişkisel tarama modelinin kullanıldığı araştırma, 2018-2019 eğitim öğretim yılında Kırıkkale Üniversitesi’nde birinci sınıftan dördüncü sınıfa kadar okuyan 551 öğrenci üzerinde gerçekleştirilmiştir. Araştırmada veri toplama araçları, Carlo ve Randal (2002) tarafından geliştirilen, Yıldız, Boz ve Yıldırım (2012) tarafından üniversite öğrencilerine uyarlananPrososyal Davranış Ölçeği ve Kandemir ve İlhan (2017) tarafından geliştirilen Kişilerarası İlişkilerde Bağlanma Stilleri Ölçeği kullanılmıştır. Hipotez test modelinin analizi için AMOS paket programlarından yararlanılarak yol analizi yöntemi kullanılmıştır. Araştırma sonucunda, üniversite öğrencilerinin güvenli bağlanma stilinin itaatkar prososyal davranışı anlamlı ve pozitif, gizli/özgeci prososyal davranışı pozitif ve anlamlı bir şekilde yordayıcı gücünün olduğu ortaya çıkmıştır. Araştırma bulgularına göre; kaygılı bağlanma stilinin kamusal prososyal davranışı yordamada pozitif ve anlamlı ve faydacı prososyal davranışı yordamada pozitif ve anlamlı bir etkisi olduğu görülmektedir. Aynı zamanda, kaçıngan bağlanma stilinin kamusal prososyal davranışı pozitif yönde anlamlı bir şekilde, faydacı prososyal davranışı anlamlı ve pozitif olarak yordadığı bulunmuştur. Araştırmanın analizi sonrasında elde edilen bulgular, alanyazındaki araştırma sonuçlarıyla karşılaştırılarak tartışılmıştır. Araştırmanın son bölümünde araştırmanın sonuçları kapsamında önerilerde bulunulmuştur.

Anahtar Kelimeler: Eğitim Bilimleri, Bağlanma Stilleri, Prososyal Davranış, Olumlu Sosyal Davranış, Yardim

\section{Giriş}

Yardım, toplumsal dayanışmayı arttıran, toplum olma bilinci sağlayan ve olması beklenen bir davranıştır. Ancak günümüzde gittikçe yardımın sadece bir kriz durumunda veya çevrenin olumlu düşüncesini kazanmak adına yapıldığını hatta bireylerin yardıma tamamen duyarsızlaştığı görülmektedir. Fanti, Vanman, Henrich ve Avraamides (2009) duyarsızlık sürecini incelemek üzere yaptıkları çalışmalarında duyarsızlığı, uyaranın tekrarlandıkça ona verilen duygusal tepkinin de azalması olarak tanımlamaktadır. Yumrukuz (2017), çalışmasında duyarsızlaşma meydana geldiğinde ahlaki değerlendirme sürecinin de bozulacağını, çünkü değerlendirme için gerekli olan ipuçlarının algılanamadığını ve dolayısıyla cevap verilmediğin söylemektedir. Bu durum gelecekte bireylerin sahip olduğu, yardım davranışının önemli bir parçası olan özgeci ve empatik davranışların daha da azalacağının, birlik ve beraberliğgin zorlaşacağının göstergesi olabilir. Bireyin başkaları için yaptığı gönüllü yardımı temel alan bir kavram olan ve son yıllarda sıklıkla karşılaşılan, "olumlu sosyal davranış" veya prososyal davranış, duyarsızlaşma perspektifinden bakıldığında daha da önemli bir hale gelmektedir. Prososyal davranışlar, bütün toplumlarda önemsenmektedir ve sosyalleşme sürecinin de en temel parçasıdır (Yöntem, 2015). Empati ve paylaşma gibi olumlu sosyal davranışlar da bu toplumsallaşma sürecine katkı sağlar ve toplumla ya da bireylerle kurulan bağların sağlıklı şekilde olması ve sürdürülmesine yardımcı olur (Özdemir, 2010).

Carlo, Hausmann, Christiansen ve Randall (2003)'e göre prososyal davranış, başka bir insanın ya da bir grup insanın yararına olabilecek, kişinin baskı altında olmadan ve kendi isteğiyle sergilediği davranışlar olarak tanımlanmıştır. Fakat bu tanımlar çok genel olduğu için beraberinde birtakım sınırlılıklar getirmektedir. Bu gibi tanımlar prososyal davranışı yapan kişinin niyetini ve sağlanan yardımın kalitesini dikkate almamaktadır (Kumru, Carlo ve Edwards, 2004). Bekkers ve Graaf (2005), prososyal davranışın, bireyin ahlâk niteliklerine ve fedakâr kişilik eğilimlerine bağlı olarak genellikle 'fedakâr davranış' biçimi olarak düşünüldüğünü ifade eder.

Carlo ve diğerleri (2003), prososyal davranışın boyutlarını altı başlık halinde toplamıştır. Bunlar; kamusal, gizli, acil, duygusal, itaatkâr ve özgeciliktir. Kamusal prososyal davranışlar, başkalarının huzurunda başkaları tarafından görülecek şekildeki istekli davranışlar olarak tanımlanmıştır. Örneğin, "İnsanlar beni izlerken başkalarına en iyi yardım edebilirim". Gizli prososyal davranışlar, başkalarının bilgisi olmadan başkalarına yardım etme eğilimi olarak tanımlanmıştır. Örneğin, "Bilmiyorum başkalarına yardım etmenin en iyi durum türü olduğuna inanıyorum". Acil prososyal davranışlar, acil durumlar veya kriz durumlarında başkalarına yardım 
Üniversite Öğrencilerinin Bağlanma Stilleri ile Prososyal Davranış Arasındaki İlişkilerin...1217

etmek demektir. Örneğin, "Gerçek krizde olan veya ihtiyacı olan insanlara yardım etme eğilimindedir". Duygusal prososyal davranışlar, duygusal bir hatırlatıcının bulunduğu durumlarda hayata geçirilen davranışlardır. Örneğin, "Durum son derece duygusal olduğu zaman başkalarına en iyi şekilde yardımcı olmaya yanıt veriyorum". İtaatkar prososyal davranışlar, bireyden istenildiği taktirde başkalarına yardımcı olmasından ibarettir. Örneğin, "İnsanlar onlara yardım etmemi istediğinde tereddüt etmem". Özgecilik, kendine çok az veya hiç algılanan doğrudan ve açık bir ödül için bir potansiyel olmadığında başkalarına yardım etmektir. Örneğin, "Yardım etmem için herhangi bir şey elde etmem gerektiğini düşünsem bile çoğunlukla yardım ederim" (Carlo ve dĭg., 2003).

Prososyal davranışı etkileyen faktörlerden biri de bağlanmadır. Kim ve Stevens'e (1987) göre, yardımlaşma ve paylaşma gibi olumlu sosyal davranışlar, bireylerin toplumla bağ kurmasını ve bu bağların sağlıklı bir şekilde devamını kolaylaştırır. Buna göre bağlanmanın yaşandığ bu gelişimsel süreci anlaşılır kılması ve süreç içerisindeki prososyal davranışın rolüne değinmesi açısından çalışma önem arz etmektedir. Sosyalleşmenin temellerini oluşturan kavramlardan biri olan bağlanmayı Bowlby (1980), bebek ile ona bakım veren arasındaki yakınlaşma sonucu oluştuğunu ve sonrasında bu duyguyu başkalarına karşı genellemesi olarak açıklar. Aynı zamanda insanların kendileri için önemli arz eden kişilere geliştirdikleri güçlü, duygusal bağdır (Bowlby, 1982). Bağlanma ayrıca, bireyin korktuğunda, yorulduğunda, hasta olduğunda bir figürle ilişki kurmak veya yakınlık aramak için duyduğu güçlü bir istek olarak da tanımlanır (Bowlby, 1982). Bowbly'e (1969) göre, bağlanma doğuştan gelen bir ihtiyaç ve bir potansiyeldir. Davis, Tongeren, Hook, Davis ve Worthington (2003) diğer tanımlara benzer bir şekilde, insanın dünyaya geldiği andan itibaren koruma, rahatlık ve destek alma gibi ihtiyaçları için güvendiği bir veya daha fazla kişi ile duygusal bağlar kurmaya çalıştığını ifade eder. Bu bağ özellikle bebeklik döneminde birincil bakıcı ile kurulmaya çalışılır. Bağlanma teorisi, bakıcı ne kadar yakınsa çocukluğun hayatta kalma şansı o kadar fazlalaşır varsayımına dayanarak, bağlanma davranışının asıl işlevinin tehlikeli bir durumdan korunmak olduğunu savunan psikanalist ve psikiyatrist Jhon Bowlby (1982) tarafindan ortaya konulmuştur.

Bowbly (1969), bağlanma davranışını dört evreden oluştuğunu söylemiştir. Aynı zamanda çocuğun hangi evrede bağlanma yaşayacağının, bağlanmanın nasıl tanımlanıldığına göre değişeceğini ifade etmiştir. Birinci evre "Figürün Sınırlı Ayrımıyla Yönelim ve Sinyaller" olarak isimlendirilmiştir. Bu evre doğumdan sekiz haftaya kadar sürer ve on iki haftalığa kadar da çıkabilir. Hatta elverişsiz koşullarda bu süre daha da uzayabilir. Bu evrede bebek kendine özgü bir biçimde başkalarını ayırt ettiğini belli eder ancak bu ayırt etme sadece koku ya da işitme ile sınırlıdır. "Bir ya da Birden Fazla Ayrı Figüre Yönelme ve Yöneltilen Sinyaller" adındaki ikinci evre yaklaşık altıncı aya ya da koşullara göre sonrasına kadar devam eden bu evrede, birincideki gibi bebek insanlara arkadaşça davranmaya devam eder. Ancak başkalarının yerine anne figürüne yönelmeyi tercih eder. Üçüncü evre olan "Sinyallerin yanı sıra Lokomosyon Aracılığıyla Ayrı bir figüre Yakınlığın Korunması" ise genellikle altıncı yedinci ay arasında başlar fakat anne figürüyle az temasta bulunan bebeklerde on ikinci aya kadar ertelenebilir ya da iki-üç yaş boyunca devam edebilir. Bebek artık daha iyi bir şekilde bireyleri ayırt eder ve bunun yanında uzaklaşan anne figürünü takip eder, döndüğünde onu karşılar. Hatta anneyi merkeze alarak çevreyi keşfe çıkar. Aynı zamanda etrafındaki diğer bireylere karşı sergilediği dostça tavır azalır, ikinci bir bağlanma figürü seçer. Figür olarak seçmediği diğerlerine ise artan bir tedbirle yaklaşır. Dördüncü ve son evre olan "Hedef Düzeltimli Bir Partnerliğin Biçimlenmesi” ise çocuk anneyi artık hareket eden bağımsız bir nesne olarak algılamaya başlar. Annenin yakınlaşmasının ya da uzaklaşmasının sebeplerini kavrayabilecek bir algıya sahip olduğu söylenemeyebilir. Ancak zamanla bu durum değişebilir ve çocuk annenin planlamalarını kavrar.

Bowbly'nin bağlanma kuramından ilk deneysel bulguları elde eden kişi ise Kanadalı Psikolog Ainsworh'tur (Bretherton, 1992). Ainsworth yaptığ 1 "Yabancı Oda Deneyleri" ile bağlanma teorisine ilk büyük katkıyı sağlamıştır. Ainsworth (1979), bebekler üzerinde yaptığı bu çalışmada 
kontrollü uyarılara yanıt olarak bebeklerdeki gözlemlenebilir davranışlardan yola çıkmıştır. Yapılan deneyler sonucu çocukların anneleriyle ve tanımadıkları yabancı bir kişiyle ayrılmalarını ve tekrar birleşmelerini dikkate alarak üç önemli davranış biçimi tespit etmişlerdir. Ainsworth (1989) bağlanmayı; güvenli ve güvensiz olarak ikiye; güvensiz bağlanmayı ise kaygıl1- kararsız ve kaçınan olmak üzere iki gruba ayırmıştır. Böylelikle bağlanmayı güvenli, kaygıl1/kararsız ve kaçıngan bağlanma biçimi olarak üç başlık altında toplamıştır.

Ainsworth'a (1979) göre güvenli bağlanmanın en önemli belirtisi, çocuğun anneyi, çevreyi keşfederken güvenli bir üs olarak kullanmasıdır. Yapılan deney sonucunda güvenli bağlanma gerçekleştirmiş olan çocukların, anneleri yokken kendilerini biraz rahatsız hissettikleri ancak annelerin geri dönmesiyle onları kucakladıkları ve sıcaklık göstererek rahatladıkları görülmüştür. Kaçıngan bağlanma stiline sahip çocukların ise annelerinin gitmesinden herhangi bir rahatsızlık hissetmedikleri ve geri döndüklerinde de ilgisizliklerini devam ettiriyor gibi göründükleri saptanmıştır. Son olarak kaygıl1/kararsız olarak sınıflandırılan çocukların annelerinin gitmesi durumunda iki farklı durumun açığa çıktığı görülmüş̧ür. İlk olarak anneleri gittiğinde ağlamışlardır, diğer kısım ise anneleri geri döndüğünde sevinmiş, sarılmışlardır fakat aniden annelerini protesto amacı ile sinirli görünmeye başlamışlardır. Anneleri onları sakinleştirmeye çalıştığında ise sinirlilik düzeyleri devam etmiştir (Hamarta, 2004). Ayrıca çevreyi keşfetmek yerine annelerine sıkıca yapışıp birlikte olmak istemektedirler. (Sümer ve Güngör, 1999)

Mikulincer, Shaver, Gillath ve Nitzberg (2005), prososyal davranışın özgeci boyutunu temel alarak yaptıkları çalışmada sıkıntıda olan bir bireye yardım edilip edilmeme davranışı incelenmiştir. $\mathrm{Bu}$ araştırmada katılımcılar bir takım görevler gerçekleştirmişlerdir. Sonrasında işbirlikçiler sıkıntı içine girecekleri durumla karşılaşmış ve asıl katılımcıya sıkıntıdaki kişinin yerine geçip ona yardım etme şansı tanımışlardır. Bu süreçte katılımcılara kendileri için güvenli bir figürün ya da sadece bir tanıdıklarının adı söylenmiş̧ir. Yaptıkları beş çalışmanın üçünde kaçıngan bağlanmayı gerçekleştiren bireyler yardım için düşük düzeyde istek ve şefkat gösterdikleri ancak güvenliği sağlayacak bir figürün temsilini görmeleri ile isteksizliklerinde azalma olduğu görülmüsştür. Shaver, Mikulincer ve Shemesh-Iron'ın (2010) yaptı̆̆ çalışmada davranışsal sistem kavramı açılanmıştır. Ardından bakım veren ile bireysel farklılıkların bağlanma stilini nasıl etkilediği araştırılmıştır ve bakım sisteminin hiperaktivasyonunu ve devre dışı bırakılmasını ölçen Bakım Sistemi Ölçeği'nin (Caregiving System Scale/CSS) geliştirilmesini açıklanmıştır. Daha sonra bu iki sürecin diğer optimal ve en uygun olmayan bakım önlemleriyle nasıl ilişkili olduğunu gösterilmiştir. Ayrıca, yeni bakım stratejisi boyutlarının, daha önce incelenen bağlanma kaygısı ve kaçınma boyutlarıyla ne ölçüde ilişkili olduğunu ve bunlardan ne kadar farklı olduğu incelenmiştir. Bu çalışma bağlanma stili ve prososyal davranış arasındaki ilişkinin farklı araştırmalarla incelenmesinin yolunu açmaktadır.

Hastings, Utandale ve Sullivan'a (2007) göre bireyin dünyaya gelmesi ile bağlanma süreci başlamaktadır. Gelişim boyunca çocuğa gösterilen sıcak ilgi, karşılıksız sevgi ve güvenli bir bağlanma ilişkisi gibi faktörler empatik ve prososyal gelişimi olumlu yönde etkiler. Anne ve babasına güvenli bağlanmış bireylerin bağlanma güvenliği ile prososyal davranış arasında bir ilişki bulunmaktadır ve dolaylı olarak bağlanma prososyal davranışı destekler niteliktedir (Einsenberg, Fabes ve Spinrad, 2006). Araştırma, bu ilişkinin açıklanabilirliğine katkı sağlaması açısından önem taşımaktadır.

Yurtdışında yapılan çalışmalara bakıldığında genel olarak güvenli bağlanma sağlandığında prososyal davranışın arttığı sonuçları görülmektedir. Yapılan bu çalışmada ise prososyal davranışın boyutları gönüllülük ve niyetlilik olarak karşımıza çıkmakta ve bağlanma stillerinin bu boyutlar üzerinde etkisi olduğu görülmektedir. Böylelikle yurtdışındaki bu boşluğu doldurması, literatüre destek sağlaması açısından önemlidir. Aynı zamanda ileride yapılacak çalışma alanlarında kullanılabilecek olması araştırmanın önemine katkı olarak değerlendirilmektedir. 
Üniversite Öğrencilerinin Bağlanma Stilleri ile Prososyal Davranış Arasındaki İlişkilerin...1219

Türkiye'de bağlanma stilleri ve prososyal davranış kavramları ayrı çalışmalarda ele alınmıştır fakat bu iki kavram aynı araştırma içerisinde yer almamaktadır. Bu çalışmanın bu iki kavramı bir arada bulundurma yönünden, bir ilk olma niteliği taşıması ve bu çalışmanın literatüre katk1 ve destek sağlaması bakımından önemli olduğu düşünülmektedir. Aynı zamanda araştırma prososyal davranışın temelini anlamada kavramsal bir model çalışması olması açısından önemlidir. Benzer bir şekilde bu araştırmada, üniversite öğrencilerinin bağlanma stillerinin, prososyal davranış1 yordayıcı güçleriyle ilgili elde edilen sonuçları, ebeveynlere verilen eğitimler, eğitimcilere verilen eğitimler gibi alanlara kavramsal ve uygulama açısından önemli veriler sağlayabileceği düşünülmektedir.

\section{Yöntem}

Araştırmanın yöntem bölümünde, araştırmanın yapıldığı model, araştırma verisinin toplandığı araştırma grubu, veri toplama araçları ve veri analiz yöntemleri hakkında bilgiler verilmişstir.

\section{Araştırmanın Modeli}

İlişkisel tarama modeli araştırmanın modeli olarak belirlenmiştir. Bu model, en az iki değişken arasında birlikte değişim düzeylerini belirlemeyi amaçlayan araştırma modelidir (Cohen, Manion ve Morrison, 2000; Karasar, 2014). Ünersite öğrencilerinin bağlanma stilleri ile prososyal davranışları arasındaki ilişkilerin incelendiği bu araştırmada ise, prososyal davranış değişkenleri ve bağlanma stil değişkenlerinin birlikte değişim düzeyleri belirlenmeye çalışıldığında, araştırma modelinin ilişkisel model olduğu söylenebilir.

\section{Araştırma Grubu}

Araştırma grubu, Kırıkkale Üniversitesi'nde bulunan ve farklı fakültelerde okumakta olan 549 öğrenciden oluşturmaktadır. 549 kişilik çalışma grubunun 396'sı (\%72.1) kadınlardan, 153'ü ise (\%27.9) erkeklerden oluşmaktadır. Ölçek uygulanan öğrencilerin yaş aralığı 17-30'dur. Yaş ortalamas1 20.11, standart sapmasi ise 2.27 dir.

\section{Veri Toplama Araçları}

1.Prososyal Davranış Ölçeği: Carlo ve Randal (2002) tarafindan üniversite öğrencilerinin prososyal davranış düzeylerini belirlemek için hazırlanan "Prososyal Davranış Eğilimi Ölçeği”" Kumru, Carlo ve Edwards (2004) tarafından Türkçe' ye uyarlanmıştır. Yapılan bu uyarlama çalışması 11-21 yaş grubu üzerinde olduğu rapor edilen ölçeğin, üniversite öğrencileri üzerindeki uyarlama çalışması Yıldız, Boz ve Yıldırım (2012) tarafından yapılmıştır (Doğan, 2015). Bu araştırmada Yıldız, Boz ve Yıldırım'ın (2012) çevirisi kullanılmıştır. Ölçek 23 maddeliktir ve beşli likert tipindedir. Yapı geçerliliği ve güvenirliğini belirlemek için Marmara Üniversitesi İşletme Bölümü lisans ve yüksek lisans öğrencilerinden olmak üzere 440 kişiye ulaşılmıştır. Yapılan analiz sonucunda KMO değerinin 0,50 den büyük $(0,778)$, Bartlett değerinin 0,05 den küçük $(0,00)$ olduğu görülmüştür. Bu ölçeğe göre gizli, kamusal, özgeci ve itaatkâr olmak üzere dört boyut bulunmaktadır. Elde edilen boyutlar incelendiğinde birinci faktörün (gizli) varyansın \%17,07, ikinci faktörün (kamusal) varyansın \%14,47, üçüncü faktörün (özgeci), varyansın \% 13,77 ve dördüncü faktörün (itaatkâr) varyansın \%11,64 olmak üzere ölçeğin toplam açıklama düzeyinin 56,96 seviyesinde olduğu görülmüştür. Güvenirlik kat sayıları ise birinci faktör için .68, ikinci faktör için .69, üçüncü faktör için .64 ve dördüncü faktör için .66 olarak bulunmuştur.

$\mathrm{Bu}$ ölçeğin üzerinden uzun süre geçmesi sebebiyle yeni veriler toplanmıştır. Güvenirlik ve belirlenen faktör yapılarının geçerliğinin test edilmesi amacıyla Doğrulayıcı Faktör Analizi (DFA) yapılmıştır. $\mathrm{Bu}$ analiz, değişkenlerin önceden tanımlanmış yapıları üzerinde ağırlıklı olarak var olacağı şeklindeki bir varsayımı temel alınmıştır. Bundan dolayı, ilgili değişkenler, yaklaşım ya da teorinin varsayımlarına göre tercih edilir ve değişkenlerin belirlenen faktörlerde ne düzeyde yer 
aldıkları incelenir. DFA ile boyutlar arasında oluşan ilişkiler, karşılaştırmalı hipotez modelleri test edilebilir ve modellerin iyilik derecesi belirlenebilir (Sümer, 2000). Buna göre oluşturan modelde ölçeğin temel yapısı DFA yapılarak uyum değerleri elde edilmiştir.

DFA sonucunda değerlerin Ki-Kare $\left(x^{2} / s d\right)=2.25$ ve RMSEA değeri .05 olduğu görülmüştür. RMSEA ve $\mathrm{x}^{2} / \mathrm{sd}$ sonuçlarının .08 'ten düşük olduğu DFA analizi sonucunda belirlenmiştir. DFA sonrasında diğer önemli uyum iyiliği sonuçları ise CFI $=.94$, GFI $=.95$, AGFI $=.94, \mathrm{IFI}=.94, \mathrm{NFI}=.90$ ve TLI $=.91$ olduğu belirlenmiştir. CFI, GFI, AGFI, IFI, NFI ve TLI, uyum iyi sonuçlarının .90 'ın üstünde olmasının yanında $\mathrm{x}^{2} / \mathrm{sd}$ ve RMSEA değerinin .08 değerinin altında olması önerilen modelin uyum yeterliliğinin kabul edilebilir düzeyde olduğunu göstermektedir. (Şimşek, 2007). DFA ile yapılan analizin sonucunda, madde ve faktör arasındaki ilişki değerlerine ait katsayılarla ilgili bulgular ise Şekil 7'de verilmiştir.

Şekil 1: Prososyal Davranış Ölçeği DFA Sonuç Diyagramı

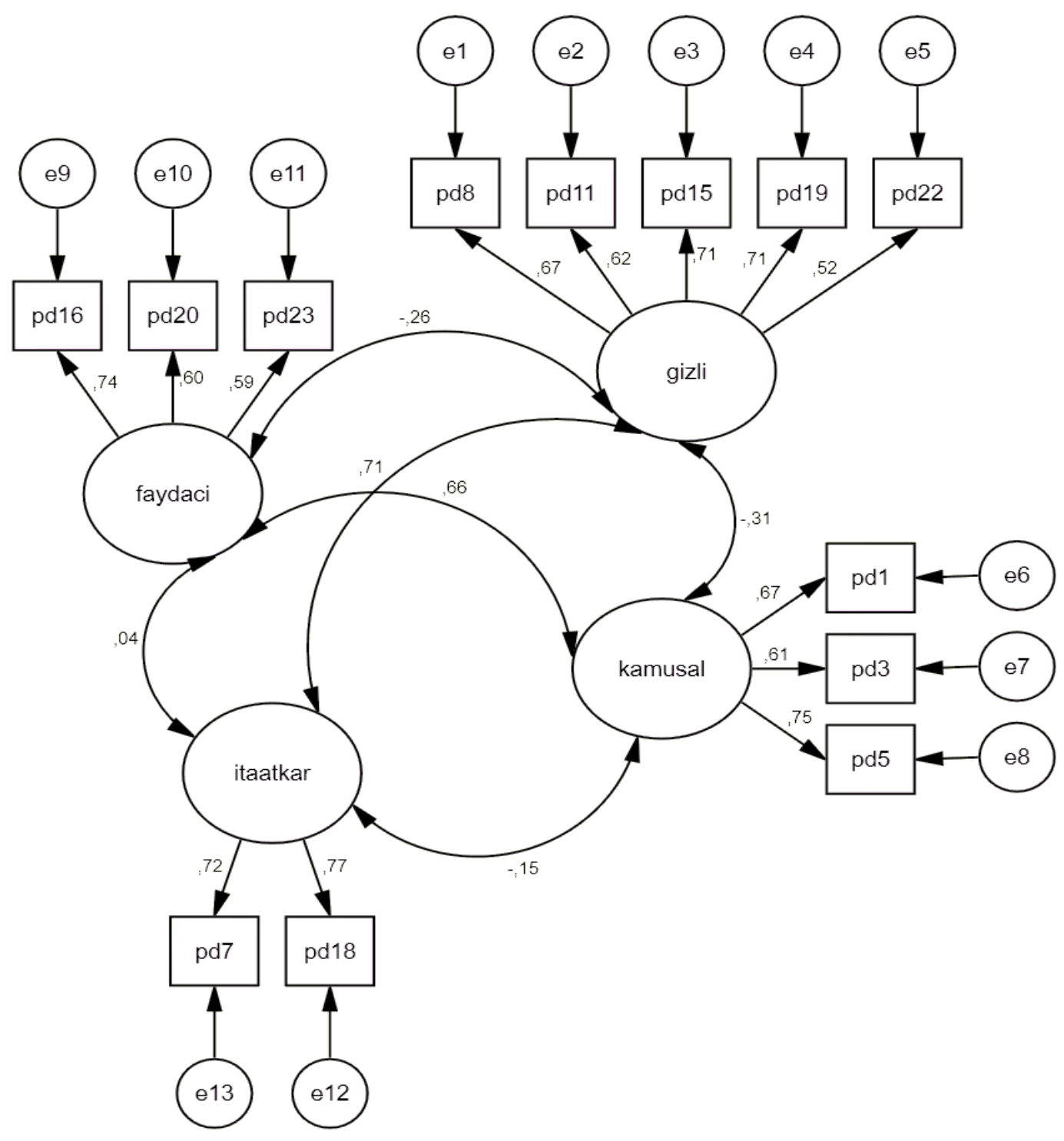

$\mathrm{Bu}$ araştırmadaki veri grubu üzerinden yapılan analiz sonuçlarına göre ise; Kaise-MeyerOlkin $(\mathrm{KMO})=.87$ ve Barlett Testi sonucu $\chi 2=3408,749(\mathrm{p}<.00)$ olarak bulunmuştur. Tüm boyutları incelendiğinde toplam açıklama düzeyinin 52,95 seviyesinde olduğu görülmüştür. Güvenirlik kat 
Üniversite Öğrencilerinin Bağlanma Stilleri ile Prososyal Davranış Arasındaki İlişkilerin...1221

sayıları ise birinci faktör için (gizli/özgeci) .71, ikinci faktör için (itaatkar) .69, üçüncü faktör için (kamusal) .69, dördüncü faktör için ise (faydac1) .66 olarak bulunmuştur.

2. Kişilerarası İlişkilerde Bağlanma Stilleri Ölçeği: Bowbly’in bağlanma teorisi dikkate alınarak Kandemir ve İlhan (2017) tarafindan geliştirilmiş̧ir. Kişilerarası bağlanma stillerini ayrışrıabilmek amacıyla 7'li likeret olarak hazırlanan ölçeğin geçerlilik ve güvenirlik çalışması Kırıkkale Üniversitesi Eğitim Fakültesi’nde öğrenim gören, 368 öğrenci üzerinde yapılmıştır. Yapılan Acımlayıcı Faktör Analizi sonrasında, Bowbly'in sınıflandırması olan "güvenli", "kaygıll" ve "kaçınmacı" üçlü yapıya ulaşıldığı ölçeğin öz değerleri; güvenli bağlanma için 3.179, kaygılı bağlanma için 2.768 ve kaçınmacı bağlanma için ise 1.997 olduğu görülmektedir. "Kişilerarası Bağlanma Stilleri Ölçeğinin", Açımlayıcı Faktör Analizi sonrasındaki, faktörlenebilirlik değeri .46 ile .76 arasında değiştiği ölçeğin güvenli bağlanma boyutu varyansın \%17,66'sını; kaygılı bağlanma boyutu varyansın \% \% 15.37'sini, kaçınmacı boyutunun ise \%11.09'unu ve toplamında ise varyansın \%44,12' sini açıladığı ortaya çıkmıştır. Yapılan Cronbach alfa iç-tutarlılık katsayıları analizi sonrasında, güvenli bağlanma için .80, kaygılı bağlanma için .74 ve kaçınmacı bağlanma için .72 olarak sonuçlar rapor edilmiştir. Faktör analizi sonrasında ulaşılan yapının doğruluğunu test edildiği DFA sonrasında, kabul edilebilir uyum düzeyine ulaşışdığı bulunmuştur. Analiz sonrasında, $x^{2} / s d=$ 3.15 ; $\mathrm{RMSEA}=.06, \mathrm{CFI}=.91, \mathrm{GFI}=.92, \mathrm{AGFI}=.91, \mathrm{IFI}=.90, \mathrm{NFI}=.90$ ve $\mathrm{TLI}=.91$ uyum iyiliği bulgularına ulaşılmıştır.

\section{Verilerin Analize Hazırlanması}

Yapılan betimsel çalışmanın sonucunda elde edilen veriler SPSS ve AMOS paket programında analiz edilmiştir.

Araştırmanın hipotezlerini test etmek için veri toplanmış ve toplanan veriler SPSS 21'e girildikten sonra, analize hazırlanması için, kayıp veri analizi, normallik, doğrusallık analizleri, araştırma gurubunun tanımlanması amacıyla da betimsel analizler yapılmıştır. Ayrıca, çoklu bağlantı sorununun ve korelasyon yetersizliği sorunlarının olup olmadığını belirlemek amacıyla korelasyon analizi yapılmıştır. Analizde yapılan bu işlemler şu şekilde özetlenebilir: Araştırma verisinde yer alabilecek ve araştırma sonucunu etkileyebilecek ihtima dahilindeki aykırı ve uç değerler öncelikle tespit edilmiştir. Verilerin, frekans dağılımları incelenmiştir. Doğrusallık için araştırma değişkenlerinin kendi aralarındaki ilişkileri incelenmiştir. $\mathrm{Bu}$ inceleme korelasyon analizinde .05 anlamlılık düzeyinde gerçekleşmiş ve analiz sonrasında doğrusallıkla ilgili bir problem olmadığı görülmüştür. Regresyon analizlerinin ön koşullarından biri ikili ve çoklu değişkenliğin olmamasıdır (Çokluk, Şekercioğlu ve Büyüköztürk, 2012). Bağımsız değişkenlerin ikisi arasında güçlü bir ilişki katsayısı olduğunda iki değişkenin "birlikte değişkenlik", ikiden fazla bağımsız değişken arasında güçlü bir ilişki katsayısı olduğunda ise çoklu değişkenlik olabilir (Kandemir, 2017). Sonuç olarak, yordayıcı değişkenler arasındaki ilişkiler .80 üzerinde olursa bu durum veri setinde çoklu bağlantı sorunun olduğunun bir işaretidir (Büyüköztürk, 2011). Korelasyon sonuçları incelenerek ikili ve çoklu değişkenliğin olup olmadığına bakılmıştır. Değişkenler arasında 80 üzeri bir korelasyon katsayısı olmadığı için değişkenler arasında çoklu değişkenlik sorununun olmadığı söylenebilir.

\section{Bulgular}

Üniversite öğrencilerinin bağlanma stillerinin prososyal davranışı yordayıcıllı̆ı̆ının incelendiği araştırmanın bu bölümünde, değişkenlere ait betimsel analizler, değişkenler arasındaki korelasyon analizi test edilmiş ve kavramsal modele ilişkin analiz sonuçlarına yer verilmiştir. Öncelikli olarak, terapötik ittifak, bağlanma stilleri, genel öz yeterlik ve danışma öz yeterlik ölçeğinden alınan betimsel sonuçlar incelenmiş ve sonuçları Tablo 1'de verilmiştir. 
Tablo 1: Değişkenlerle İlgili Betimsel Analiz Sonuçları

\begin{tabular}{lccccc}
\hline & $\mathrm{N}$ & En Az & En Çok & $\overline{\mathrm{x}}$ & Ss \\
\hline Güvenli & 549 & 1.29 & 7.14 & 4.94 & 1.03 \\
Kaygılı & 549 & 1.00 & 7.00 & 3.94 & 1.17 \\
Kaçıngan & 549 & 1.00 & 10.83 & 3.71 & 1.08 \\
İtaatkar & 549 & 1.00 & 5.00 & 3.86 & .93 \\
Faydacı & 549 & 1.00 & 5.00 & 2.50 & 1.04 \\
Kamusal & 549 & 1.00 & 5.00 & 1.90 & .87 \\
Gizli & 549 & 1.20 & 5.20 & 3.93 & .81 \\
\hline
\end{tabular}

Tablo 1 incelendiğinde, araştırmanın bağımlı değişkeni olan güvenli bağlanma stiline ait ortalama puanın kaçıngan ve kaygılı bağlanma stillerine ait ortalama puanlardan daha yüksek olduğu belirlenmiştir. Görüldüğü gibi, bağlanma stillerinden kaçıngan bağlanma stilinden alınan puan diğer bağlanma stillerine göre daha düşüktür. Bunun yanında, araştırma grubundakilerin kamusal prososyal davranış ortalama puanı, itaatkâr, faydacı ve gizli prososyal davranışın ortalama puanından daha düşüktür. Prososyal davranışın faktörlerinden en yüksek ortalamaya sahip olan faktörün ise gizli prososyal davranış olduğu görülmüş̧ür.

Araştırmada, araştırma grubunun bağlanma stillerinden güvenli bağlanma, kaygılı bağlanma ve kaçıngan bağlanma ile prososyal davranıştan gizli, itaatkar, kamusal ve faydacı prososyal davranışın ortalama puanları arasındaki korelasyon incelenmiş ve sonuçları Tablo 2'de verilmiştir.

Tablo 2: Değişkenler Arası Korelasyon Analiz Sonuçları

\begin{tabular}{lcccccc}
\hline Değişkenler & Güvenli & Kaygll & Kaçıngan & Gizli & Kamusal Faydac1 & İtaatkar \\
\hline Güvenli & 1 & & & & & \\
Kaygılı & $.16^{* *}$ & 1 & & & & \\
Kaçıngan & $-.09^{*}$ & .08 & 1 & & & \\
Gizli & $.26^{* *}$ & .04 & .02 & 1 & & \\
Kamusal & -.05 & $.18^{* *}$ & $.26^{* *}$ & $-.17^{* *}$ & 1 & \\
Faydacı & -.01 & $.26^{* *}$ & $.23^{* *}$ & $-.15^{* *}$ & $.43^{* *}$ & 1 \\
İtaatkar & $.41^{* *}$ & $.11^{*}$ & -.02 & $.50^{* *}$ & -.07 & .01 \\
\hline
\end{tabular}

${ }^{*} p<.05, * * p<.01$

Korelasyon analizi sonucunda, bağlanma stillerine ait faktörler ile prososyal davranışa ait faktörler arasında anlamlı ilişkiler olduğu görülmüştür. Bu tabloya göre, güvenli bağlanma ile kaygılı bağlanma $(\mathrm{r}=.16)$, gizli prososyal davranış $(\mathrm{r}=.26)$ ve itaatkar prososyal davranış arasında pozitif yönde, düşük düzeyde, anlamlı bir ilişkisi, kaçıngan bağlanma $(\mathrm{r}=-.09)$ ile ise negatif yönde düşük düzeyde anlamlı bir ilişkisi olduğu görülmüştür. Kaygılı bağlanma ile kamusal prososyal davranış $(\mathrm{r}=.18)$, faydacı prososyal davranış $(\mathrm{r}=.26)$ ve itaatkar prososyal davranışın $(\mathrm{r}=.11)$ arasında pozitif yönde düşük düzeyde ve anlamlı bir ilişkisi olduğu görülmüştür. Kaçıngan bağlanma ile kamusal prososyal davranış $(\mathrm{r}=.26)$ ve faydacı prososyal davranış $(\mathrm{r}=.23)$ arasında pozitif yönde düşük düzeyde anlamlı bir ilişkinin olduğu görülmüş̧ür. Gizli prososyal davranış ile kamusal ( $r=-.17)$ ve faydacı $(\mathrm{r}=-.15)$ prososyal davranışın arasında negatif yönde düşük düzeyde anlamlı bir ilişkinin olduğu, itaatkar prososyal $(\mathrm{r}=.50)$ davranış ile ise pozitif yönde orta düzeyde anlamlı bir ilişki 
Üniversite Öğrencilerinin Bağlanma Stilleri ile Prososyal Davranış Arasındaki İlişkilerin...1223

görülmüştür. Kamusal prososyal davranış ile faydacı prososyal davranış arasında ( $\mathrm{r}=.43)$ arasında pozitif yönde orta düzeyde anlamlı bir ilişki görülmüştür. Bu sonuçlara göre üniversite öğrencilerinin bağlanma stillerinin prososyal davranışı yordayıcı ve ara değişkenleri ile pozitif ya da negatif ilişkisi olduğu görülmüştür ve böylece model testi için gerekli korelasyon yeterliliğine ulaşıldığını söylemek mümkünüdür. Daha sonra kavramsal modelin test edilmesi işlemine geçilmiştir. Test edilecek kavramsal model Şekil 8'de verilmiştir.

Şekil 2: Kavramsal Model

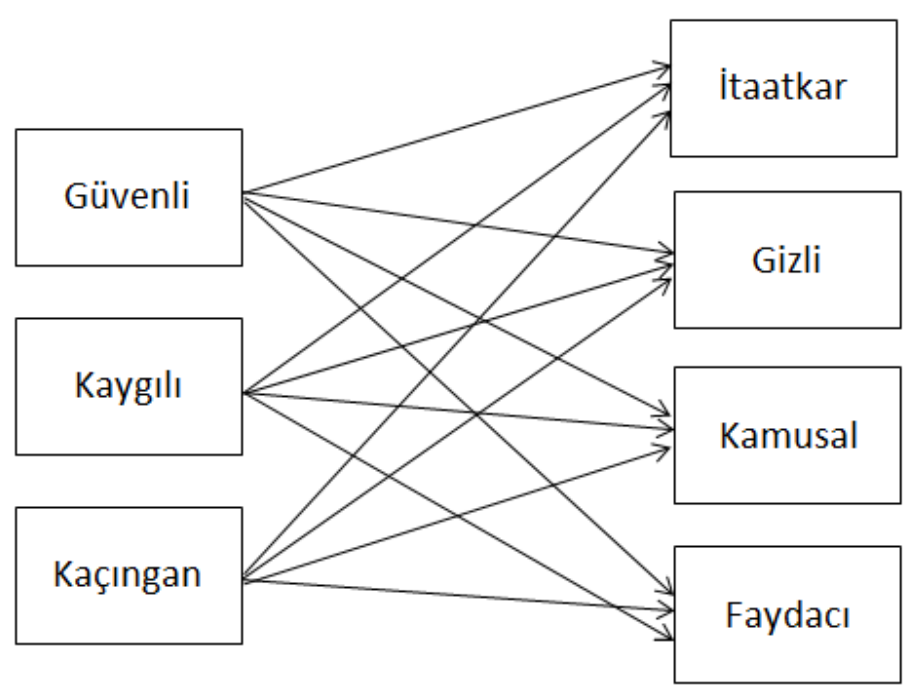

Şekil 2'deki test edilecek kavramsal model incelendiğinde, güvenli bağlanma, kaygılı bağlanma ve kaçınmacı bağlanma stillerinin faydacı prososyal davranış, kamusal prososyal davranış, itaatkar prososya davranış ve gizli/özgeci prososyal davranışı doğrudan yordayabileceğine ilişkin yol diyagramları görülmektedir. Daha sonra kavramsal modelin analizi yapılmıştır. Sonuçları Şekil 3'te gösterilmiştir.

Şekil 3: Bağlanma Stillerine İlişkin Oluşturulan Modelin Analiz Sonuçları

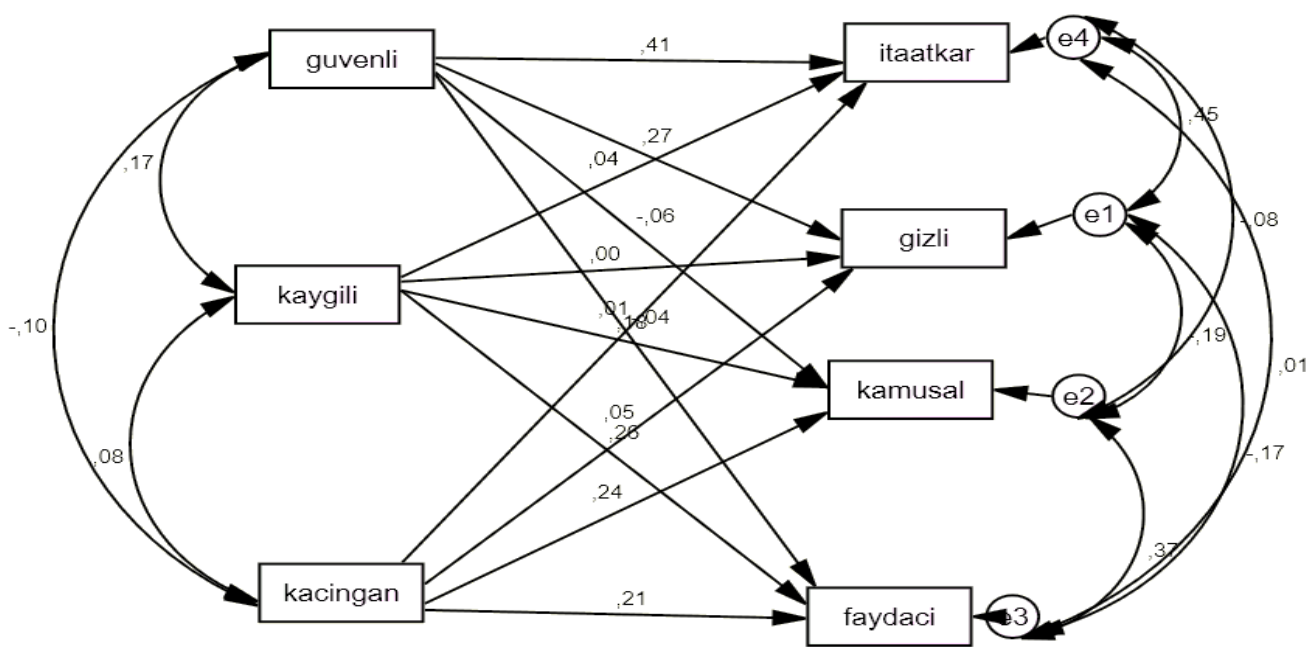

Şekil 3’te görülen analiz sonuçlarına bakıldığında güvenli bağlanma, kaygılı bağlanma ve kaçıngan bağlanma stillerinin; itaatkâr, gizli, kamusal ve faydacı prososyal davranış üzerinden 
yordayabileceğine ilişkin yol diyagramları görülmektedir. Aynı zamanda, güvenli, kaçıngan ve kaygılı bağlanma stillerinin ve gizli kamusal, faydacı ve itaatkâr prososyal davranış değiş̧enlerinin birbirlerini doğrudan etkileyebileceği path diyagramları çizilmiştir. Test edilmiş modelin etki katsayıları incelendiğinde güvenli bağlanmanın kamusal prososyal davranışı $(\beta=-06, t<3)$ değerinde anlamsız düzeyde etkilediği ve iki değişken arasındaki korelasyon değerine bakıldığında da anlamlı bir ilişkinin olmadığı $(\mathrm{r}=.5)$ görülmüştür. Ayrıca güvenli bağlanma ile faydacı prososyal davranış arasında $(\beta=.01, t<3)$ değerinde anlamsız bir etki bulunmaktadır ve korelasyon ilişkisinde de $(\mathrm{r}=.01)$ anlamlı bir ilişki olmadığı sonucuna ulaşılmıştır. Kaygılı bağlanmanın gizli prososyal davranışı $(\beta=.00, t<3)$ değerinde anlamsız etkisi olduğu görülmüştür ve kaygılı bağlanma ile gizli prososyal davranış arasında anlamlı bir ilişki olmadığı $(\mathrm{r}=.04)$ görülmüştür. Son olarak kaçıngan bağlanma stili ile itaatkar prososyal davranış arasında anlamsız bir ilişki olduğu $(\mathrm{r}=-.02)$ ve yine gizli prososyal davranış ile de arasında anlamsız bir ilişki olduğu (r=.02) görülmüştür. Bu sonuçlara göre düşünüldüğünde, hipotez test modelde bu değişkenler arasındaki yordayıcı ilişki çıkartılarak model tekrar test edilmiştir. Sonuçları Şekil 4'te gösterilmiştir.

Şekil 4: Bağlanma Stillerine İlişkin Oluşturulan Nihai Modelin Analiz Sonuçları

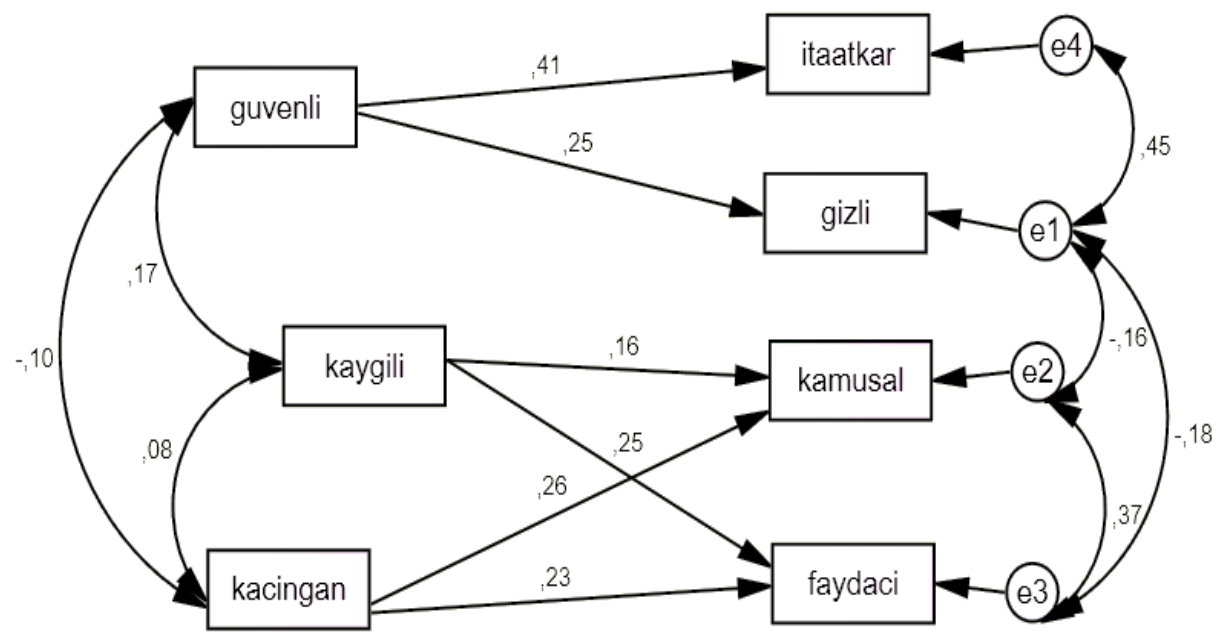

Sonuçlar incelendiğinde, CFI $=.99$, GFI $=.98$, AGFI $=.99$, IFI $=.99$, NFI $=.98$ ve TLI $=$ .99 , olduğu görülmüştür. Analiz sonrasında, RMSEA $=.01$ ve $\chi^{2} / \mathrm{sd}=1.35$ olduğu belielenmiştir. $\chi^{2}$ / sd ve RMSEA değerlerinin .05'ten küçük olduğu ve CFI, GFI, AGFI, IFI, NFI, TLI değerlerinin .95 değerinin üzerinde olduğu araştırma sonuçlarına göre, test edilen hipotez modelin mükemmel uyum gösterdiği istatistik alan yazınına göre söylenebilir (Şimşek, 2007). Bu yüzden iyileştirme indekslerinin incelenmesine gerek duyulmamıştır.

Üniversite öğrencilerinin bağlanma stillerinin prososyal davranışı yordayıcıllğına yönelik model testinde doğrudan etkiye dönük elde edilen ilişkiler incelendiğinde, üniversite öğrencilerinin güvenli bağlanma stilinin itaatkar prososyal davranışı yordama düzeyinin pozitif yönde ve anlamlı şekilde olduğu görülmektedir $(\beta=.41, \mathrm{t}=10.58, \mathrm{p}<.01)$. Araştırma sonucunda güvenli bağlanma stilinin gizli prososyal davranışı yordamada pozitif ve anlamlı bir etkisi olduğu görülmüştür $(\beta=.25$ $\mathrm{t}=6.18, \mathrm{p}<.01$ ). Araştırma sonucunda kaygılı bağlanma stilinin kamusal prososyal davranışı anlamlı ve poztif yönde doğruladığ 1 görülmektedir $(\beta=.16, \mathrm{t}=4.04, \mathrm{p}<.01)$. Araştırma sonucunda kaygılı bağlanma stilinin faydacı prososyal davranışı yordamada pozitif ve anlamlı bir etkisi olduğu görülmüştür $(\beta=.25, \mathrm{t}=6.25, \mathrm{p}<.01)$. Araştırma sonucunda, kaçıngan bağlanma stilinin kamusal prososyal davranışı pozitif yönde ve anlamlı bir şekilde yordadığ görülmüştür $(\beta=.26, t=6.37$, $\mathrm{p}<.01$ ). Buna göre "Kaçıngan bağlanma stili kamusal prososyal davranışı yordamaktadır (H11)" 
Üniversite Öğrencilerinin Bağlanma Stilleri ile Prososyal Davranış Arasındaki İlişkilerin...1225

hipotezi doğrulanmaktadır. Araştırma sonucunda kaçıngan bağlanma stilinin faydacı prososyal davranışı anlamlı ve pozitif yönde yordamada etkisi olduğu görülmüştür $(\beta=.23, \mathrm{t}=5.71, \mathrm{p}<.01)$.

Araştırmada, üniversite öğrencilerinin kaygılı bağlanma stili ile gizli prososyal davranış arasında korelasyon analizi sonucunda anlamlı bir ilişki bulunmadığından ( $\mathrm{r}=.04)$, araştırmanın hipotezlerinin test edildiği analizinde bu ilişki hipotezi çıkartılmıştır. Aynı şekilde güvenli bağlanma stili ile kamusal prososyal davranış arasındaki korelasyon analizi sonucunda anlamlı bir ilişki bulunamadığı için ( $\mathrm{r}=.05)$, bu ilişki hipotezi çıkarılmıştır. Bu araştırmada güvenli bağlanma stili ile faydacı prososyal davranış arasındaki korelasyon analizi sonucunda anlamlı bir ilişki bulunamamıştır $(\mathrm{r}=.01)$ ve ilişki hipotezi çıkarılmıştır. Araştırmada kaçıngan bağlanma stili ile gizli prososyal davranış arasındaki korelasyon analizinde anlamlı bir sonuç çıkmaması nedeniyle $(\mathrm{r}=.02)$, hipotezlerin test edildiği analizde bu ilişki hipotezi çıkarılmıştır. Bu araştırmada kaçıngan bağlanma stili ile itaatkar prososyal davranış arasındaki korelasyon analizinde anlamlı bir sonuç çıkmaması nedeniyle ( $\mathrm{r}=-.02)$, hipotezlerin test edildiği analizde bu ilişki hipotezi çıkarılmıştır.Tartışma, Sonuç ve Öneriler

$\mathrm{Bu}$ bölümde araştırmanın analizi sonrasında elde edilen bulgular ile kavramsal çerçeve kısmındaki araştırma sonuçları karşılaştırılmış ve değişkenlerle ilgili literatürde bulunan bilgiler değerlendirilerek tartışılmıştır.

Araştırma sonucunda bağlanma stillerinin prososyal davranışı anlamlı düzeyde yordadığ ortaya çıkmıştır. Bağlanma stillerinin yordayıcılı̆̆ına bakıldığında güvenli bağlanmanın prososyal davranıșın olumlu yönü olarak adlandırabileceğimiz gizli (özgeci) ve itaatkar prososyal davranıș1 pozitif yönde yordadığı görülmektedir. Alanyazınına bakıldığında direkt olarak bu durumu destekleyen çalışmalar olmasa da prososyal davranış ile ilgili olabilecek kavramların (empati, özgecilik, sosyal beceri gibi) güvenli bağlanma ile pozitif yönde ilişkisi olduğu görülmüş̧ür (Guerro ve Jones, 2003; Sambo, 2010; Hurter, 2014). Güvensiz bağlanma stilleri olarak da bilinen kaygılı ve kaçınmacı bağlanma stilinin ise prososyal davranışın olumsuz olan yönü olarak görebileceğimiz faydacı ve kamusal prososyal davranışı da pozitif yönde yordamaktadır. Bu sonuca göre güvensiz bağlanan bireylerin kamusal ve faydacı prososyal davranışı gösterdiği görülmektedir. Ancak beklenen durum bireylerin prososyal davranışın gönüllü boyutlarını oluşturan ve içten gelen yardımı temsil eden gizli (özgeci) ve itaatkar prososyal davranışı göstermesidir. Başka bir deyişle güvensiz bağlanan bireyler toplum tarafından onay almak gibi kendi faydalarının ön planda olduğu niyetli prososyal davranışları sergilemeleri yerine güvenli bağlanma stiline sahip bireylerde olduğu gibi prososyal davranışı içsel ve yarar beklemeksizin yapmaları beklenmektedir. Bu durumu destekleyen bu araştırmanın analizleri sonucunda ortaya çıkan kavramsal modelde ise kaçıngan ve kaygılı bağlanmanın kamusal ve faydacı prososyal davranışı yordarken, güvenli bağlanma stilinin gizli/özgeci ve itaatkar prososyal davranışı yordadığı görülmektedir. Eisenberg, Fabes ve Spinrad (2006), güvenli bağlanan çocukların kendileriyle ilgilenen bir bağlanma figürüne sahip oldukları için, çocuğun güvenli bağlanması ile prososyal eğilimleri arasındaki ilişkiye dair bulguların, ailevi yakınlıkla çocukların prososyal gelişimleri arasındaki bağlantıyı dolaylı olarak destekler nitelikte olduğunu söylemektedir. Güvenli bağlanmayı gerçekleştirmiş bireyler için, başkalarına yardım etmek, kişisel koruma hedeflerine yardım etmez. Çünkü zaten birey kendini güvende hissediyordur. Tam tersine, güvenlik duygusu yaşadığ 1 için kendini korumaya harcayacağ 1 enerjiyi ve dikkati serbest bırakır ve empatik tutum sergilemesini sağlar (Shaver, Mikulincer ve Chun, 2008). Bu durum yapılan bu araştırmayı desteklemektedir.

Prososyal davranışta bağlanmanın sağlandığı figürün de etkisi olduğu söylenebilir. Bebeğin figür ile bağlanma gerçekleștirmesi figürün bebeğin ihtiyaç anlarında yanında olduğu anlamına gelmektedir ve bebeklerin öğrenmede model alma yöntemi kullandıkları bilinmektedir. Buna göre bir davranış olan prososyal davranışın öğrenilmesinde figürün model olması önem arzedebilir. Uzmen'e (2001) göre de bireylerin prososyal davranışı göstermelerinde model olmanın rolü oldukça 
büyüktür. Prososyal davranış, aile içinde öğrenme ve aile bireyleri tarafından sağlanan modelleme ile gelişir (Uzmen, 2001). Buna göre Eisenberg, Fabes ve Spinrad (2006) ve Uzmen (2001) birbirini doğrulamaktadır. Yüksek lisans kapsamında yazılan bu araştırma ise güvenli bağlanma gerçekleştirmiş bireylerin gizli ve itaatkar olumlu sosyal davranışın birbirini yordadığııı göstererek model almanın önemine destek sağlamış olmaktadır.

Bağlanma ile ilgili yurtdışı kaynakları tarandığında direkt olarak prososyal davranış ile ilgili bir çalışmaların az olduğu görülmüştür. Türkiye'de ise böyle bir çalışmaya rastlanmamıştır. Bu sebeple prososyal davranış ile ilgili olduğu düşünülen diğer kavramlara bakılmıştır. Bu kavramlardan biri olan sosyal beceri; olumlu-olumsuz duyguları anlatabilme, kişisel haklarını savunabilme, başkalarından yardım isteyebilme, kendisine uygun olmayan isteklere hayır diyebilme gibi kişilerin başkaları ile olumlu etkileşimi başlatmaları ve sürdürmeleri için önemli davranış öğelerini içermektedir. (Çetinkaya-Yıldız ve Toprak, 2016). Bununla birlikte sosyal beceri kavramının temelinde de empati yatmaktadır (Riggio, Tucker ve Coffaro, 1989) ve Duru (2004) de yapmış olduğu çalışmada empati ile yardım etme eğilimi ilişkisine bakmışır. Buna göre empati ve yardım etme eğilimi arasında pozitif yönde bir ilişki bulunmuştur. Başka bir değişle bireyde empati arttıkça yardım etme davranışı da artmaktadır. Bu durum da prososyal ile ilgili olan ilişkiyi güçlendirmektedir. Çetinkaya-Yıldız ve Toprak'ın (2016) yaptıkları araştırmada sosyal becerisi yüksek olan bireylerin STK'ya üye olma ya da diğer bir değişle başkalarına yardım etme davranışının doğru orantılı olduğu görülmüştür. Bu durum da güvenli bağlanma gerçekleştirmiş bireylerin STK'ya üye olmak veya yardım etmek için girişken olmak gibi prososyal davranışı destekleyen davranışları gerçekleştirdikleri söylenebilir. Yüksek lisans tezi kapsamında yapılan bu çalışmanın güvenli bağlanan bireylerin gizli ve itaatkar prososyal davranışı sergilemeleri öncesinde yapılan bu araştırmaları destekler niteliktedir.

Güngör (2000), kaçıngan bağlanma stiline sahip bireylerin kendini ifade etmekte ve başkaları ile iletişime girmekte zorlandığını, olumlu olumsuz duygularını ifade etmede güçlük yaşadığını belirtmiştir. Kaygılı bağlanma stiline sahip bireylerin sosyal ilişkilerinde yaşadıkları zorluk sebebiyle bu durumun prososyal davranışa da yansıyabileceği söylenebilir. Yüksek lisans tezi kapsamında yapılan bu araştırmanın sonucu olan kaygılı bağlanmanın kamusal ve faydacı prososyal davranışı yordaması da bunu destekler ve aynı zamanda bireylerin kendi içten gelen bir motiveden ziyade çevrenin isteği veya takdirini almak için yapmış olduğu gösterir.

Güvenli bağlanma gerçekleştiren bireyler, hem kendilerini hem de başkalarını olumlu olarak değerlendirme eğilimindedir (Hazan ve Shaver, 1987). Böylelikle başkaları ile kolay iletişim kurabilmektedirler. Kendilerini sosyal yeterlilik açısından rahat hissederler. Sosyal yeterlilik ile güvenli bağlanmanın pozitif yönde anlamlı ilişki gösterdiğini sunan bir araştırmayı da Tavakoli, Jomehri ve Farrokhi (2014) yapmıştır. Buna göre sosyal anlamda yeterlilik gösteren bireyler güvenli bağlanma gerçekleştirmiş bireylerdir ve kendi yetkinliklerinin farkında oldukları için olumlu sosyal davranış gerçekleştirmede zorlanmayacakları söyelenebilir.

Ayrıca, bireylerin bağlanma stiline göre prososyal davranışların farklı boyutlarını gerçekleştirmesiyle bağlanmanın bireyin tercihlerindeki farklılıkların temelini oluşturduğu söylenebilir. Bu konu ile ilgili Waters, Hamilton ve Weinfield'in (2000) yaptığı araştırmaya göre bebeklikte oluşan bağlanma stilinin yetişkinlikteki bireysel farklılıklar üzerinde etkili olduğu söylenmektedir. Bu araştırmaya paralel olarak Wei, Rusell ve Zakalik (2015), güvenli bağlanma stili gerçekleştiren bireylerin kişisel-sosyal alanda daha yetkin, girişken olduklarını söylemiştir. Bireyin anne ile oluşturacağı bağlanma stili ilerleyen yaşlarda zamanla oluşacak olan prososyal davranışın üzerinde de etki gösterebilir. Mevcut araştırmamızda güvenli bağlanmanın gizli (özgeci) prososyal davranışı yordaması yardım davranışının geçmişte anne figürü ile kurulan güvenli bir bağlanmanın sonucu olarak içten geldiğini, niyetli olmayıp aksine gönüllü olduğunu gösterebilir. Ayrıca Svetlova, Nichols ve Brownell (2010), iki yaşından itibaren eyleme yönelik gerçekleştirilen prososyal 
davranışın karşı tarafın ince ipuçlarından gelen duyguları anlamakla mümkün olduğunu, bunun ise ancak açık bir iletişim ile gerçekleşebileceğini söylemiştir.

Hazan ve Shaver (1987) güvenli bağlanma stilini gerçekleştiren bireylerin kendilerine dair değer algılarının yüksek olduğunu ve yine bu bireylerin kişilerarası ilişkilerinde rahat ve girişken olduklarını belirtmiştir. Aynı araştırmada kaygılı bağlanma stiline sahip bireylerinse reddedilme, dışlanma gibi durumlar için kaygı ve endişe duydukları sonucuna ulaşmıștır. Bulgulara göre kaçıngan ve kaygılı bağlanma stili ile faydacı ve kamusal prososyal davranışın birbirini yordadığı görülmüştür. Hazan ve Shaver'in (1987) araştırmaları ışığında toplum içine girmekten çekinen ve korkan kaygılı bağlanma stilini gerçekleştiren bireylerin kendilerine değer vermeyip, çevresindeki bireylere değer verdiği durumu da göz önüne alınarak yardım etme durumları da gönüllü olarak içten değil, çevresinde bulunan ve değerli gördügü bireyleri memnun etmek adı altındaki bir niyet için yapıldığını gösterebilir.

Laible, Carlo ve Rafaelli (2000), ergenlikte gerçekleşen güvenli bağlanma stilinin yardıma muhtaç insanlara merhametli olduğu ve empatik tepkilere olumlu katkı sağladığı sonuçlarına ulaşmıştır. Buna göre araştırmamızın bulgularında da görüldüğü gibi güvenli bağlanmaya sahip bireylerde prososyal davranışın görülme ihtimali, kaçıngan veya kaygılı bireylerden daha fazla olduğu söylenebilir. Ancak bu sonuca zıt olarak Saroglou (2005) yaptığı çalışmada böyle anlamlı bir farklılığın olmadığını söylemiştir.

Araştırma bulgularına göre yapılan korelasyon analizinde güvenli bağlanma ve kaygılı bağlanmanın, gizli prososyal davranış ve itaatkar prososyal davranış arasında pozitif yönde düşük düzeyde anlamlı bir ilişki görülmüştür. Kaygılı bağlanma stili ile kamusal prososyal davranış, faydacı prososyal davranış ve itaatkar prososyal davranışın arasında pozitif yönde düşük düzeyde anlamlı bir ilişki bulunmuştur. Kaçıngan bağlanma stili ile kamusal prososyal davranış ve faydacı prososyal davranış arasında ise pozitif yönde düşük düzeyli anlamlı bir ilişki olduğu sonucuna ulaşılmıştır.

Ayrıca bağlanma stillerinin prososyal davranış üzerinde etkisi olduğu görülmüştür. Araştırmaya göre güvenli bağlanma stilinin, prososyal davranışın gizli prososyal davranış ve itaatkar prososyal davranış boyutlarını pozitif yönde yordadığı; kaygılı bağlanma stili ve kaçıngan bağlanma stilinin ise faydacı prososyal davranış ve kamusal prososyal davranışı pozitif yönde yordadığı sonucuna ulaşılmıştır. Güvenli bağlanma stilini gerçekleştiren bireyler olumlu sosyal davranış1 gönüllü olarak başkalarının haberi olmadan, kendisinden yardım istendiğinde tereddüt etmeyen ya da karşılığında bir şey almayı düşünmeden yapılan davranışını sergilerken; kaçıngan ve kaygılı bağlanma stiline sahip bireyler ise niyetli olarak, yapılan davranıştan bir fayda sağlayacağını umut ederek, başkalarının görebileceği bir şekilde davranışlarını sergiledikleri söylenebilir. Buna göre bağlanma stillerinin prososyal davranışı yordayıcı önemli bir değişken olduğu sonucu ortaya çıkmıştır.

Araştırma sırasında literatür taraması yapılırken bağlanma stillerinin bebeklikten itibaren oluşmaya başladığının bilinmesine rağmen araştırmaların çoğunun ergenler, üniversite öğrencileri ve yetişkinler üzerinde yoğunlaştığ görülmüsşür. İlkokul ve okulöncesi kademelerinde de bu konunun araştırılması önem arz etmektedir. Bireylerin bağlanma stillerinin olumlu sosyal davranışı etkilediği görülmüştür. Bağlanma stillerinin küçük yaşta oluşmasıyla bireylerde prososyal davranışın temelleri de şekillenmektedir. Bu durumda bireyin bağlanma stili önem taşımaktadır. Konu ile ilgili bağlanmanın gerçekleşeceği bireye yani anne figürüne öncesinde eğitimler verilip, toplumun da ihtiyacı olan olumlu sosyal davranışın artması sağlanabilir. Üniversite öğrencilerinin bağlanma stilleri ile prososyal davranış arasındaki ilişkiyi inceleyen çalışmaya rastlanamamıştır. Dolayısıyla benzer özellikler gösteren çalışma grupları üzerinde yürütülecek çalışmalar araştırma bulgularının genellenebilirliğini arttırabilir. Bağlanma stillerinin belirlenmesinde bakım-veren kişinin etkisi göz önünde bulundurulduğunda anne-babanın aile içi rollerini ve işlevlerini daha etkili yerine 
getirebilmesini sağlayacak aile eğitimi gibi projeler gerçekleştirilebilir. Üniversite öğrencileri üzerinden yapılan bu araştırmada ilişkisel bir yol izlenmiştir. Farklı araştırmalarda boylamsal yöntem kullanılabilir. Araştırmada güvenli bağlanmanın prososyal davranışı olumlu ve pozitif yönde yordadığ 1 sonucuna ulaşılmıştır. Ancak araştırmada aracı değişken kullanılmamıştır. Farklı aracı değişkenlerin kullanılmasıyla araştırmanın yordayıcılığı da değişebilir. Örneğin Kholberg'in Ahlak Gelişimi Teorisi değişken olarak kullanılabilir. Kaçıngan ve kaygılı bağlanma stili gerçekleştiren bireyler toplum içinde güvenli bağlanma gerçekleştirenlere göre daha az katılmakta, geride durmakta ve sosyal ilişkilerde daha arka plandadırlar. Güvensiz bağlanma stiline (kaygılı ve kaçıngan) sahip bireylere ilgili eğitimler verilerek bağlanma stilleri hakkında farkındalıkları arttırılabilir. Böylelikle kendine inanan bireyler prososyal davranışı gerçekleştirme de daha rahat davranabilirler. Geçerlik ve güvenirliği tekrar edilen Prososyal Davranış Ölçeği'nin analiz sonucunda ortaya çıkan yapısı başka çalışmalarda test edilebilir. Kullanılan Prososyal davranış ölçeği altı boyutu olan prososyal davranışın dört boyutunu ölçmektedir. Geliştirilen farklı ölçeklerle boyutların tamamının ölçülmesi daha sağlıklı sonuçlar sağlayacaktır.

\section{Kaynakça}

Ainsworth, M. D. S. (1979). Infant-mother attachment. American Psychologist, 34, 932-937. https://doi.org/10.1037/0003-066x.34.10.932

Ainsworth, M. D. S. (1989). Attachments Beyond İnfancy. American Psychologist, 44, 709-716. https://doi.org/10.1037/0003-066x.44.4.709

Bekkers, R. H. F. P. \& de Graaf, N. D. (2005). Field of education and prosocial behavior. Paper prepared for Marktdag Sociologie.

Bowlby, J. (1969). Bağlanma. Çev. Tuğrul Veli Soylu, Pinhan Yayıncılık, İstanbul, 2012.

Bowlby, J. (1980). Attachment and loss: Vol. 3. Loss: Sadness and depression. New York: Basic Books. https://doi.org/10.1093/sw/26.4.355

Bowlby, J. (1982). Attachment and Loss: Vol. 1. Attachment. New York: Basic Books.

Bretherton, I. (1992). The origins of attachment theory: John Bowlby and Mary Ainsworth. Developmental psychology, 28(5), 759. https://doi.org/10.1037/0012-1649.28.5.759

Büyüköztürk, Ş. (2011). Sosyal bilimler için veri analizi el kitabı. Ankara: Pegem Akademi. https://doi.org/10.14527/9789756802748

Carlo, G., Hausmann, A., Christiansen, S. \& Randall, B. R. (2003). Sociocognitive and Behavioral Correlates of a Measure of Prosocial Tendencies for Adolescents. Journal of Early Adolescence, 23(1), 107-134. https://doi.org/10.1177/0272431602239132

Carlo, G. ve Randall, B. A. (2002). The development of a measure of prosocial behaviors for late adolescents. Journal of youth and adolescence, 31(1), 31-44. https://doi.org/10.1023/a:1014033032440

Cohen, L., Manion, L., \& Morrison K. (2000). Research methods in education (5th Edition). London: Routledge Falmer.

Çetinkaya, Y. E. \& Toprak, E.(2016). Psikolojik danışman adaylarının empatik eğilim, utangaçlık, olumsuz değerlendirilme korkusu ve sosyal beceri düzeylerinin farklı değişkenler açısından incelenmesi. Mediterranean Journal of Humanities, 6(2), 513-530. https://doi.org/10.13114/mjh.2016.313 
Üniversite Öğrencilerinin Bağlanma Stilleri ile Prososyal Davranış Arasındaki İlişkilerin...1229

Çokluk, Ö., Şekercioğlu, G. \& Büyüköztürk, Ş. (2012). Sosyal bilimler için çok değişkenli SPSS ve LISREL uygulamaları. Ankara: PegemA Yayıncılık.

Davis, D.E., Van Tongeren, D.R., Hook, J.N., Davis, E.B., Worthington, E.L. \& Foxman, S. (2013). Relational spirituality and forgiveness: Appraisals that may hinder forgiveness. Psychology of Religion and Spirituality, 6(2), 102. https://doi.org/10.1037/a0033638

Doğan, F. (2015). Travma Sonrası Stres İle Prososyal Davranış Eğilimi Arasındaki İlişkide Travma Sonrası Büyümenin Arac1 Rolü. Yüksek Lisans Tezi, Sosyal Bilimler Enstitüsü Orta Doğu Teknik Üniversitesi, Ankara. https://doi.org/10.17755/esosder.548142

Duru, E. (2004). Öğretmen adaylarında empati-yardım etme eğilimi ilişkisi ve yardım etme eğiliminin bazı psikososyal değişkenler açısından incelenmesi. Pamukkale Üniversitesi Eğitim Fakültesi Dergisi, 15(15), 31-41. https://doi.org/10.31795/baunsobed.492450

Eisenberg, N., Fabes, R. A. \& Spinrad, T. L. (2006). Prosocial development. In N. Eisenberg, W. Damon, and R. M. Lerner (Eds.), Handbook of child psychology: Vol. 3. Social, emotional, and personality development (6th ed.). 646-718. New York, NY: Wiley. https://doi.org/10.1002/9780470147658.chpsy0311

Fanti, K. A., Vanman, E., Henrich, C. C. \& Avraamides, M. N. (2009). Desensitization to media violence over a short period of time. Aggressive Behavior, 35(2), 179-187. https://doi.org/10.1002/ab.20295

Guerrero, L.K. \& Jones, S.M. (2003). Differences in One's Own and One's Partner's Perceptions of Social Skills as a Function of Attachment Style. Communication Quarterly, 51(3), 277-295. https://doi.org/10.1080/01463370309370157

Güngör, D. (2000). Bağlanma stillerinin ve zihinsel modellerin kuşaklararası aktarımında ana babalık stillerinin rolü. Yayınlanmamış Doktora Tezi. Ankara Üniversitesi.

Hamarta, E. (2004). Üniversite öğrencilerinin yakın ilişkilerindeki bazı değişkenlerin (benlik saygısı, depresyon ve saplantılı düşünme) bağlanma stilleri açısından incelenmesi. Doktora Tezi, Selçuk Üniversitesi Sosyal Bilimler Enstitüsü, Konya. https://doi.org/10.33905/bseusbed.613245

Hastings, P. D., Utendale, W. T. \& Sullivan, C. (2007). The socialization of prosocial development. Handbook of socialization: Theory and research, 638-664.

Hazan, C. \& Shaver, P. (1987). Romantic love conceptualized as an attachment process. Journal of Personality And Social Psychology, 52(3), 511-524. https://doi.org/10.1037/00223514.52.3.511

Hurter, S., Paloyelis, Y., Williams, A. C. D. C. \& Fotopoulou, A. (2014). Partners' empathy increases pain ratings: effects of perceived empathy and attachment style on pain report and display. The Journal of Pain, 15(9), 934-944. https://doi.org/10.1016/j.jpain.2014.06.004

Kandemir, M. (2017) Psikolojik Danışmanlar Açısından Terapötik İttifakın İncelenmesi, Doktora Tezi, Gaziosmanpaşa Üniversitesi, Tokat.

Kandemir, M. \& İlhan, T. (2017). Kişilerarası İlişkilerde Bağlanma Stilleri Ölçeği: Geçerlik ve güvenirlik çalışması. 2. Avrasya Pozitif Psikoloji Kongresi içinde (s.174-175). İstanbul: Üsküdar Üniversitesi. https://doi.org/10.17051/ilkonline.2019.611538

Karasar, N. (2014). Bilimsel araştırma yöntemi. Ankara: Nobel

Kumru, A., Carlo, G. \& Edwards, C. P. (2004). Olumlu sosyal davranışların ilişkisel, kültürel, bilişsel ve duyuşsal bazı değişkenlerle ilişkisi. Türk Psikoloji Dergisi, 19(54), 109-125. 
Laible, D. J., Carlo, G. \& Raffaelli, M. (2000). The differential relations of parent and peer attachment to adolescent adjustment. Journal of Youth and Adolescence, 29, 45-59. https://doi.org/10.1023/a:1005169004882

Mikulincer, M., Shaver, P. R., Gillath, O. \& Nitzberg, R. A. (2005). Attachment, caregiving, and altruism: Boosting attachment security increases compassion and helping. Journal of Personality and Social Psychology, 89, 817-839. https://doi.org/10.1037/00223514.89.5.817

Özdemir, Z. (2010). Lise öğrencilerinin prososyal davranışlarının; Mizah, öfke ve utangaçlık düzeylerine göre incelenmesi (Yüksek lisans tezi, Gazi Üniversitesi, Eğitim Bilimleri Enstitüsü, Ankara). Gazi Üniversitesi Eğitim Bilimleri Enstitüsü, Ankara. https://doi.org/10.1501/ozlegt_0000000111

Riggio R. E., Tucker J. \& Coffaro D. (1989). "Social Skills and Empathy”. Personality and Individual Differences 10/1 (1989) 93-99. https://doi.org/10.1016/0191-8869(89)90184-0

Sambo, C. F., Howard, M., Kopelman, M., Williams, S. \& Fotopoulou, A. (2010). Knowing you care: effects of perceived empathy and attachment style on pain perception. PAIN, 151(3), 687-693. https://doi.org/10.1016/j.pain.2010.08.035

Saroglou, V., Pichon, I., Trompette, L., Verschueren, M. \& Dernelle, R. (2005). Prosocial behavior and religion: New evidence based on projective measures and peer ratings. Journal for the Scientific Study of Religion, 44, 323-348. https://doi.org/10.1111/j.1468-5906.2005.00289.x

Shaver, P. R., Mikulincer, M. \& Chun, D. S. (2008). Adult attachment theory, emotion regulation, and prosocial behavior. Regulating Emotions, 121-145. https://doi.org/10.1002/9781444301786.ch5

Shaver, P. R., Mikulincer, M., \& Shemesh-Iron, M. (2010). A behavioral-systems perspective on prosocial behavior. In M. Mikulincer \& P. R. Shaver (Eds.), Prosocial motives, emotions, and behavior: The better angels of our nature (p. 73-91). https://doi.org/10.1037/12061-004

Sümer, N. (2000). Yapısal eşitlik modelleri: Temel kavramlar ve örnek uygulamalar. Türk Psikoloji Yaz1lar1, 3, 6, 49-74.

Sümer, N. ve Güngör, D. (1999). Yetişkin bağlanma stilleri ölçeklerinin Türk örneklemi üzerinde psikometrik değerlendirmesi ve kültürlerarası bir karşılaştırma. Türk Psikoloji Dergisi, 14(43), 71-106.

Svetlova, M., Nichols, S. R. \& Brownell, C. A. (2010). Toddlers' prosocial behavior: From instrumental to empathic to altruistic helping. Child development, 81(6), 1814-1827. https://doi.org/10.1111/j.1467-8624.2010.01512.x

Şimşek, Ö. F. (2007). Yapısal eşitlik modellemesine giriş, temel ilkeler ve lisrel uygulamaları. Ekinoks Yayınları, Ankara.

Tavakoli, N., Jomehri, F. \& Farrokhi, N. (2014).The relationship between attachment styles and social self-efficacy with internet addiction in Iranian Students. Bulletin of Environment, Pharmacology and Life Sciences, 3, 302-307.

Waters, E., Hamilton, C. E. \& Weinfield, N. S. (2000). The stability of attachment security from infancy to adolescence and early adulthood: General introduction. Child development, 71(3), 678-683. https://doi.org/10.1111/1467-8624.00175

Wei, M., Russell, D. W. \& Zakalik, R. A. (2005). Adult attachment, social self-efficacy, selfdisclosure, loneliness, and subsequent depression for freshman college students: A 
Üniversite Öğrencilerinin Bağlanma Stilleri ile Prososyal Davranış Arasındaki İlişkilerin...1231 longitudinal study. Journal of Counseling Psychology, 52(4), 602-614. https://doi.org/10.1037/0022-0167.52.4.602

Yıldız, S., Boz, İ. T. \& Yıldırım, B. F. (2012). Kişilik tipi ile olumlu sosyal davranış arasındaki ilişki: marmara üniversitesi öğrencileri üzerinde bir araştırma. Ataturk University Journal of Economics \& Administrative Sciences, 26(1). https://doi.org/10.30798/makuiibf.349660

Yumrukuz, Ö. (2017). Şiddete karşı duyarsızlaşma ve sosyal medya ilişkisi üzerine bir inceleme. Marmara İletişim Dergisi, 28, 89-106. https://doi.org/10.17829/midr.20172833779

Yöntem, M. K. (2015). Özgecilik. Terzi, Ş., ve Tekinalp B. (Editör). Eğitimde Pozitif Psikoloji. Ankara: PegemA yayınc1lık. https://doi.org/10.14527/9786053180685.11 